Pacific Journal of Mathematics

AN EXTENSION OF LANDAUS THEOREM ON 


\section{AN EXTENSION OF LANDAU'S THEOREM ON TOURNAMENTS}

\section{J. W. MooN}

In an ordinary (round-robin) tournament there are $n$ people, $p_{1}, \cdots, p_{n}$, each of whom plays one game against each of the other $n-1$ people. No game is permitted to end in a tie, and the score of $p_{i}$ is the total number $s_{i}$ of games won by $p_{i}$. By the score sequence of a given tournament is meant the set $S=\left(s_{1}, \cdots, s_{n}\right)$, where it may be assumed, with no loss of generality, that $s_{1} \leqq \cdots \leqq s_{n}$. Landau [3] has given necessary and sufficient conditions for a set of integers to be the score sequence of some tournament. The object of this note is to show that these conditions are also necessary and sufficient for a set of real numbers to be the score sequence of a generalized tournament; a generalized tournament differs from an ordinary tournament in that as a result of the game between $p_{i}$ and $p_{j}, i \neq j$, the amounts $\alpha_{i j}$ and $\alpha_{j i}=1-\alpha_{i j}$ are credited to $p_{i}$ and $p_{j}$, respectively, subject only to the condition that $0 \leqq \alpha_{i j} \leqq 1$. The score of $p_{i}$ is given by

$$
s_{i}=\sum_{j=1}^{n} \alpha_{i j},
$$

where the prime indicates, for each admissible value of $i$, that the summation does not include $j=i$.

THeOREM. $A$ set of real numbers $S=\left(s_{1}, \cdots, s_{n}\right)$, where $s_{1} \leqq$ $\ldots \leqq s_{n}$, is the score sequence of some generalized tournament if and only if

$$
\sum_{i=1}^{k} s_{i} \geqq\left(\begin{array}{l}
k \\
2
\end{array}\right),
$$

for $k=1, \cdots, n$ with equality holding when $k=n$.

Proof. The necessity of these conditions is obvious since (1) simply requires that the sum of the scores of any proper subset of the players be at least as large as the number of games played between members of this subset and that the sum of all the scores be equal to the total number of games played.

For terminology and results on flows in networks which will be used in the proof of the sufficiency of the above conditions see Gale [2]. A network $N$ is constructed whose nodes are $x_{1}, \cdots, x_{n}$ and

Received January 23, 1963. 
$y_{1}, \cdots, y_{n}$. The node $x_{i}$ is joined to the node $y_{j}$ by an are of capacity $c\left(x_{i}, y_{j}\right)=1$, if $i \neq j$. All other ordered pairs of nodes are joined by an arc of capacity zero. A demand $d$ is defined on the nodes of $N$ as follows: $d\left(x_{i}\right)=-s_{i}$ and $d\left(y_{i}\right)=l_{i}=(n-1)-s_{i}$. From (1) it follows that $-s_{i} \leqq 0 \leqq l_{i}$ for all $i$. It is not difficult to show, using the second formulation of the feasibility theorem in [2] (or see Fulkerson [1]), that this demand will be feasible if

$$
\sum_{i=1}^{k} l_{i} \leqq \sum_{i=1}^{k} \min \left\{s_{i}, k-1\right\}+\sum_{i=k+1}^{n} \min \left\{s_{i}, k\right\},
$$

for $k=1, \cdots, n$. We shall show that (1) implies (2) and that from the feasibility of the demand $d$ we can ultimately infer the existence of a generalized tournament having $S$ as its score sequence.

For each of the above values of $k$ let $t=t(k)$ be the largest integer less than or equal to $k$ such that $s_{t} \leqq k-1$; let $t(k)=0$ if $s_{1}>k-1$. It follows from (1) that

$$
\begin{aligned}
\sum_{i=1}^{k} \min \left\{s_{i}, k-1\right\}=\sum_{i=1}^{t} s_{i}+(k-1)(k-t) \\
\geqq\left(\begin{array}{l}
t \\
2
\end{array}\right)+(k-1)(k-t)=\left(\begin{array}{l}
k \\
2
\end{array}\right)+\left(\begin{array}{c}
k-t \\
2
\end{array}\right) \geqq\left(\begin{array}{l}
k \\
2
\end{array}\right) .
\end{aligned}
$$

Also, for each such value of $k$, let $h=h(k)$ be the largest integer less than or equal to $n-k$ such that $s_{k+h} \leqq k$; let $h(k)=0$ if $s_{k+1}>k$. Then

$$
\begin{aligned}
\sum_{i=k+1}^{n} \min \left\{s_{i}, k\right\} & =\sum_{i=1}^{k+h} s_{i}-\sum_{i=1}^{k} s_{i}+k(n-k-h) \\
& \geqq\left(\begin{array}{c}
k+h \\
2
\end{array}\right)+k(n-k-h)-\sum_{i=1}^{k} s_{i} \\
& =\left(\begin{array}{l}
h \\
2
\end{array}\right)-\left(\begin{array}{l}
k \\
2
\end{array}\right)+k(n-1)-\sum_{i=1}^{k} s_{i},
\end{aligned}
$$

using (1) again and rearranging slightly. Combining (3) and (4) and using the definition of $l_{i}$ we see that (2) will hold if

$$
k(n-1)=\sum_{i=1}^{k} l_{i}+\sum_{i=1}^{k} s_{i} \leqq\left(\begin{array}{l}
h \\
2
\end{array}\right)+k(n-1),
$$

which certainly holds for all $k$.

By definition the feasibility of the demand $d$ means that there exists a flow $f$ on the network such that

$$
\sum_{i=1}^{n} f\left(x_{i}, y_{j}\right) \geqq l_{j}, \quad j=1, \cdots, n,
$$


and

$$
\sum_{j=1}^{n} f\left(y_{j}, x_{i}\right) \geqq-s_{i}, \quad i=1, \cdots, n,
$$

where $f(u, v)$ denotes the flow along the arc from $u$ to $v$ and such that $f(u, v) \leqq c(u, v)$ and $f(u, v)+f(v, u)=0$ for all ordered pairs of nodes. These constraints and the fact that $\sum_{j=1}^{n} l_{j}=\sum_{i=1}^{n} s_{i}$ imply that equality holds throughout in (5) and (6), that $0 \leqq f\left(x_{i}, y_{j}\right) \leqq 1$ for all $i \neq j$, and that $f\left(x_{i}, y_{i}\right)=0$ for all $i$.

Let

$$
\alpha_{i j}=\frac{1}{2}\left(f\left(x_{i}, y_{j}\right)-f\left(x_{j}, y_{i}\right)+1\right),
$$

for all $i \neq j$. From the above properties of $f$ it may easily be verified: that

$$
\begin{aligned}
0 \leqq \alpha_{i j} & \leqq 1 \\
\alpha_{i j}+\alpha_{j i} & =1,
\end{aligned}
$$

and that

$$
\sum_{j=1}^{n} \alpha_{i j}=\frac{1}{2}\left[s_{i}-l_{i}+(n-1)\right]=s_{i}, \quad \text { for } i=1, \cdots, n .
$$

These three properties of the $\alpha_{i j}$ 's are precisely those which are used to define a generalized tournament whose score sequence is $S$. Hence the existence of the flow $f$ implies the existence of a generalized tournament having $S$ as its score sequence, which suffices to complete the proof of the theorem.

I wish to thank Professor Leo Moser for suggesting this problem. to me. Professor H. J. Ryser has kindly informed us that he also has recently obtained a proof of this theorem.

\section{REFERENCES}

1. D. R. Fulkerson, Zero-one matrices with zero trace, Pacific J. Math., 10 (1960), 831-836.

2. D. Gale, A theorem on flows in networks, Pacific J. Math., 7 (1957), 1073-1082.

3. H. G. Landau, On dominance relations and the structure of animal societies. III. The condition for score structure, Bull. Math. Biophys. 15 (1953), 143-148.

UNIVERSITY COLLEGE LONDON 



\section{PACIFIC JOURNAL OF MATHEMATICS}

\section{EDITORS}

RalPh S. Phillips

Stanford University

Stanford, California

M. G. Arsove

University of Washington

Seattle 5 , Washington
J. Dugundu

University of Southern California

Los Angeles 7, California

Lowell J. Paige

University of California

Los Angeles 24, California

\section{ASSOCIATE EDITORS}
E. F. BECKENBACH
D. DERRY
H. L. ROYDEN
E. G. STRAUS
T. M. CHERRY
M. OHTSUKA
E. SPANIER
F. WOLF

\section{SUPPORTING INSTITUTIONS}

\author{
UNIVERSITY OF BRITISH COLUMBIA \\ CALIFORNIA INSTITUTE OF TECHNOLOGY \\ UNIVERSITY OF CALIFORNIA \\ MONTANA STATE UNIVERSITY \\ UNIVERSITY OF NEVADA \\ NEW MEXICO STATE UNIVERSITY \\ OREGON STATE UNIVERSITY \\ UNIVERSITY OF OREGON \\ OSAKA UNIVERSITY \\ UNIVERSITY OF SOUTHERN CALIFORNIA
}

\author{
STANFORD UNIVERSITY \\ UNIVERSITY OF TOKYO \\ UNIVERSITY OF UTAH \\ WASHINGTON STATE UNIVERSITY \\ UNIVERSITY OF WASHINGTON \\ AMERICAN MATHEMATICAL SOCIETY \\ CALIFORNIA RESEARCH CORPORATION \\ SPACE TECHNOLOGY LABORATORIES \\ NAVAL ORDNANCE TEST STATION
}

Mathematical papers intended for publication in the Pacific Journal of Mathematrcs should be typewritten (double spaced), and the author should keep a complete copy. Manuscripts may be sent to any one of the four editors. All other communications to the editors should be addressed to the managing editor, L. J. Paige at the University of California, Los Angeles 24, California.

50 reprints per author of each article are furnished free of charge; additional copses may be obtained at cost in multiples of 50 .

The Pacific Journal of Mathematics is published quarterly, in March, June, September, and December. Effective with Volume 13 the price per volume (4 numbers) is $\$ 18.00$; single issues, $\$ 5.00$. Special price for current issues to individual faculty members of supporting institutions and to individual members of the American Mathematical Society: $\$ 8.00$ per volume; single issues $\$ 2.50$. Back numbers are available.

Subscriptions, orders for back numbers, and changes of address should be sent to Pacific Journal of Mathematics, 103 Highland Boulevard, Berkeley 8, California.

Printed at Kokusai Bunken Insatsusha (International Academic Printing Co., Ltd.), No. 6 , 2-chome, Fujimi-cho, Chiyoda-ku, Tokyo, Japan.

\section{PUBLISHED BY PACIFIC JOURNAL OF MATHEMATICS, A NON-PROFIT CORPORATION}

The Supporting Institutions listed above contribute to the cost of publication of this Journal, but they are not owners or publishers and have no responsibility for its content or policies. 


\section{Pacific Journal of Mathematics}

\section{Vol. 13, No. $4 \quad$ June, 1963}

Dallas O. Banks, Bounds for eigenvalues and generalized convexity ........... 1031

Jerrold William Bebernes, A subfunction approach to a boundary value problem for

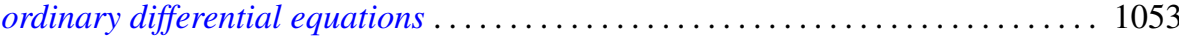

Woodrow Wilson Bledsoe and A. P. Morse, A topological measure construction . . . 1067

George Clements, Entropies of several sets of real valued functions . . . . . . . . . 1085

Sandra Barkdull Cleveland, Homomorphisms of non-commutative *-algebras . . . . . 1097

William John Andrew Culmer and William Ashton Harris, Convergent solutions of

ordinary linear homogeneous difference equations . . . . . . . . . . . . . . . 1111

Ralph DeMarr, Common fixed points for commuting contraction mappings . . . . . . 1139

James Robert Dorroh, Integral equations in normed abelian groups . . . . . . . . 1143

Adriano Mario Garsia, Entropy and singularity of infinite convolutions . . . . . . . 1159

J. J. Gergen, Francis G. Dressel and Wilbur Hallan Purcell, Jr., Convergence of extended Bernstein polynomials in the complex plane ................. 1171

Irving Leonard Glicksberg, A remark on analyticity of function algebras . . . . . . 1181

Charles John August Halberg, Jr., Semigroups of matrices defining linked operators

with different spectra ................................. 1187

Philip Hartman and Nelson Onuchic, On the asymptotic integration of ordinary

differential equations . . . . . . . . . . . . . . . . . . . . . . . . . . . . 1193

Isidore Heller, On a class of equivalent systems of linear inequalities . . . . . . . . . 1209

Joseph Hersch, The method of interior parallels applied to polygonal or multiply

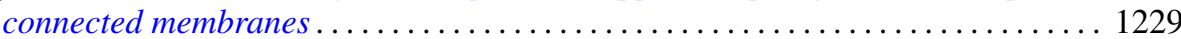

Hans F. Weinberger, An effectless cutting of a vibrating membrane . . . . . . . . . . 1239

Melvin F. Janowitz, Quantifiers and orthomodular lattices ....

Samuel Karlin and Albert Boris J. Novikoff, Generalized convex inequalities . .

Tilla Weinstein, Another conformal structure on immersed surfaces of negative

curvature.

Gregers Louis Krabbe, Spectral permanence of scalar operators

Shige Toshi Kuroda, Finite-dimensional perturbation and a representaion of

scattering operator.

Marvin David Marcus and Afton Herbert Cayford, Equality in certain

inequalities

Joseph Martin, A note on uncountably many disks .

Eugene Kay McLachlan, Extremal elements of the convex cone of semi-norms . . . . 1335

John W. Moon, An extension of Landau's theorem on tournaments . .

Louis Joel Mordell, On the integer solutions of $y(y+1)=x(x$

Kenneth Roy Mount, Some remarks on Fitting's invariants .....

Miroslav Novotný, Über Abbildungen von Mengen ............

Robert Dean Ryan, Conjugate functions in Orlicz spaces.

John Vincent Ryff, On the representation of doubly stochastic operators . . . . . . . . 1379

Donald Ray Sherbert, Banach algebras of Lipschitz functions .

James McLean Sloss, Reflection of biharmonic functions across analytic boundary

conditions with examples.

L. Bruce Treybig, Concerning homogeneity in totally ordered, connected topological space....

John Wermer, The space of real parts of a function algebra...

James Juei-Chin Yeh, Orthogonal developments of functionals and related theorems

in the Wiener space of functions of two variables......... 